\title{
E-Payment: Buzz Word or Reality
}

\author{
Vishal Acharya, S. O. Junare, Dharmesh D. Gadhavi
}

\begin{abstract}
The e-payment system in India is experiencing a massive transformation. Mobile phones and e-commerce are growing rapidly and consumers are showing affinity towards digital technology. Indian government is also stepping up by launching "Digital India" initiative to accelerate the awareness, availability and adoption of digital technologies. Today Indian govt., businessman and people are exploring the possibility to move towards a cashless economy. Still these days' cash remain main mode of transaction amongst the people. As per KPMG report 2017 and the rate of e-payment adoption is increased by approx. ten percent and expected to further increment. The purpose of the study is to analyze behavioral intentions of Indian consumer about e-payment with an application of the UTAUT2 model (unified theory of acceptance and use of technology).

This study has applied UTAUT-2 model as a conceptual framework and has considered performance expectancy, effort expectancy, facilitating conditions, hedonic motivation, and habit. For this, the study has targeted 300 respondents based on non-probability convenience sampling method. The data would be processed and analyzed using SPSS version 20 and hypotheses would be performed by applying multiple regression analysis. The biggest challenge in the growth of e-payment in Indian is skeptical mindset of people and their concern about safety and security. People scare that their device can be hacked or virus can be attacked. These serious issues should be addressed by the govt. Furthermore, India faces the challenge of limited adoption of fixed broadband. The work needs to be done in terms of improving the internet infrastructure in the country. This study is contributing to the existing body of knowledge in area of e-payment where there is a research vacuum especially in context of India. Furthermore, it helps to understand the impact of UTAUT 2 models variates on behavioral intention among Indians about e-payment which is again researched by very few people. The outcomes of this study would be beneficial to govt., policy makers, banks, online transaction facilities providers and software developers in developing strategies about e-payment acceptance and use. As this study is confined to India only, its findings may be generalized to other countries directly.
\end{abstract}

Keywords: Behavioral Intention, Digital India, e-Payment, UTAUT

\section{INTRODUCTION}

The e-payment system in India is experiencing a massive transformation. Mobile phones and e-commerce are growing rapidly and consumers are showing affinity towards digital technology. Indian government is also stepping up by launching "Digital India" initiative to accelerate the

Revised Manuscript Received on October 25, 2019

* Correspondence Author

Prof. Vishal A. Acharya,* Faculty of Management Studies, Ganpat University, Kherva, India. vishal.acharya@ganpatuniversity.ac.in

Dr. S. O. Junare, Faculty of Management, Gujarat Forensic Sciences University, Gandhinagar, India.prof.junare@gfsu.edu.in

Dr. Dharmesh D. Gadhavi, Faculty of Management Studies, Ganpat University, Kherva, India. dharmesh.gadhvi@ganpatuniversity.ac.in awareness, availability and adoption of digital technologies. Today Indian government, businessman and people are exploring the possibility to move towards a cashless economy. Still these days' cash remain main mode of transaction amongst the people. As per KPMG report 2017 and the rate of e-payment adoption is increased by approx. ten percent and expected to further increment.

India is rapidly evolving in to electronic payments. According to the Digital payment 2020- BCG (2016) report India ranked second in the world in mobile subscription. Digital infrastructure is developing very rapidly in India. Now $3 \mathrm{G}$ and $4 \mathrm{G}$ network is available even in rural part of the country. Currently 240 million consumer use smartphones and it is projected to be increase 520 million by 2020. As stated in BCG report 2016, More than 70 percent people access the internet through their smart phones and it is expected to be increased by 90 percent in few coming years. After the demonetization in 2016 the Indian people are rapidly moving from hard currency to digital, it would be interesting to know that the digital and electronic payments becomes an integral part of their lives in near future.

The payment system of any country, though advanced and sophisticated, does face various risks, viz. bank failures, frauds, counter-party failures, etc. Such aberrations could trigger a chain-reaction that might ultimately result in disruption and distrust of the payment system. Such systematic and cascading breakdown of the payment system can hinder the trust amongst the people in government payment system. These things bring the question, which factors are affecting to the adoption of e payments in India?

This study focuses on investigating the impact of the UTAUT2 model factors, trust and Government support on intention to use e-payment system among rural people in India. Present study tries to contribute in the area of e-commerce services and also in the area of digital services. The study also tries to contribute theoretically by testing UTAUT2 model with three new set of constructs. Following this section, literature on e-payment with specific note on UTAUT 2 model as framework is provided. In next section, reliability and sample description along with analysis of data are presented followed by discussion, implications and limitations of the study. 


\section{REVIEW OF LITERATURE}

\section{A. E payment}

E-commerce is considered as most powerful medium these days as it enables exchange of good, services, information to a great extent (Mehta and Sivadas, 1995). It is essential that e-commerce functions well with all the supporting system (Goldfinger and Perrin, 2001). The success or failure of e-commerce largely depends on its connection elements i.e. e-payment. Khosrow-Pour (2008) revealed that inefficient e-payment system can results into break down in the e-commerce hence it is considered as central phenomenon in the e-commerce. Additionally, the popularity of online transactions triggers the need of robust way of payment, for which traditional payment can help (Panurach, 1996). It is noted that online transactions are done either with credit card or with debit card. These day online wallets have been gaining acceptance. However, it is equally important that e-payment need to be safe, efficient and should be easy in use (Abrazhevich, 2004).

\section{B. Extended version of Unified theory of acceptance and use of technology model (UTAUT2)}

The Unified theory of acceptance and use of technology model-2 (UTAUT2) has its roots in the theories like Technology Acceptance Model (TAM) and subsequently UTAUT. Originally, UTAUT was developed to test and analyse the acceptance cum use of technology by employees (e.g. Cheong and Park, 2005). Later on the model got tested in the different segment as well. In past research, these types of models have been used to examine the relationship between the determinants of technology centric adoption behaviors ( $\mathrm{Lu}$ and $\mathrm{Su}, 2009$ ).Williams et al. (2015) believes that this is entirely as would be expected given the intention of UTAUT to assist with the measurement of the intention to adopt a new technology. By improving all the shortcomings in the first technology acceptance model, Venkatesh et al. (2012) did series of efforts and finally came with refined form of model with constructs such as habit, facilitating conditions, effort expectancy, performance expectancy, perceived value, social influence, hedonic motivation. Overall UTAUT2, is considered as comprehensive model because it contains more constructs which are capable enough to cover all the necessary dimensions related to technology adoption. Additionally, previous models, did not considered the hedonic motivation part in the technology adoption, it is UTAUT2 model which also contains the hedonic element as one of the constructs. Looking at the context of study, perceived value construct can be dropped so in the present study, the construct namely PV dropped and three new dimensions such as trust in government, trust in internet and the construct such as government support were included. As it may enhance the overall predictability of model where in the behavioural intention is taken as the dependent variable.

\section{Performance Expectancy (PE)}

In all the technology related adoptions, it is important to consider expected performance from the technology related product. It is always expected that technology helps in improving the performance of an individual so as if individual perceive certain technology as helper in improving performance then it will lead to adoption of technology (Venkatesh et al., 2003). Past research on performance expectancy suggest that there is positive relationship with its impact on actual usage. (Agarwal and Karahanna, 2000). However, the linkage of performance expectancy and usage will be incomplete without favourable behavioural intention ( $\mathrm{Lu}$ et al., 2009). Based on the extensive literature evidences, it can be postulated that

H1. Performance Expectancy (PE) will have a significant influence on Behavioural intention (BI) to use e payment services in India.

\section{Effort Expectancy (EE)}

Effort expectancy is defined as "the degree of ease associated with the use of the system" (Venkatesh et al. 2003 p. 450). The construct is associated with the dimensions like ease of understanding in its operation. It is associate with kind of efforts required to use such technology. It is also associated with the convenience of usage, it is expected that the said technology results into convenience of its usage. And finally, effort expectancy is associated with easiness or difficulty in its operation (Tak and Panwar, 2017). Past research suggest that effort expectancy affects positively to behavioural intention. Jiang et al. (2013) stated that simple and flexible payment methods, provided by the online retailer can dramatically improve consumer perceived online shopping convenience. Hence it can be postulated that:

H2. Effort expectancy (EE) will have a significant influence on Behavioural intention (BI) to use e payment services in India.

\section{E. Social influence (SE)}

According to Chong et al. (2010), SI is "the degree to which an individual user perceives the importance others believes he or she should use an innovation" (p. 136). Mahadeo (2009) stated that there are two kind of SI which is internal and interpersonal. Internal influence can be due to professional opinion and media information factors while interpersonal influence arises due to many factors such as word-of-mouth from friends, colleagues and superiors. According to Hong, and Kang (2011) SI can be influence majorly through peer pressure. In this same line, Puschel et al. (2010) stated that SI can be applied within a similar environment like friends, Family or individuals. Various past researches highlighted the importance of social influence in influencing behavioural intention (Tan et al., 2012) TAM model applied in Malaysia and trough UTAUT model by (Yu, 2012; Lewis et al., 2013) Therefore, it is hypothesized that:

$\mathrm{H} 3$. Social influence (SI) will have a significant influence on Behavioural intention (BI) to use e payment services in India.

\section{F. Facilitating conditions (FC)}

FC is termed as the access to infrastructure and resource play a critical role in consumer perception i.e as the accessibility of consumer increases the chances of adoption of e-Payment will also increase

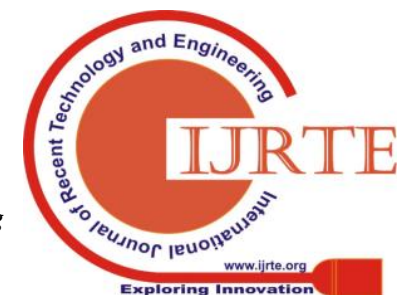


(Venkatesh et al., 2003, 2012). In many studies, it has been observed that when consumers have equipment or gadgets like computer, Laptop, credit card, POS and etc. for processing of payment then it can lead to increase usage intention (Taylor and Todd, 1995; Joshua and Koshy 2011).

H4. Facilitating conditions (FC) will have a significant influence on Behavioural intention (BI) to use e payment services in India

\section{G. Hedonic motivation (HM)}

HM refers to "the fun or pleasure gained from accepting and using a particular technology" (Brown and Venkatesh, 2005). Many authors have termed that HM as fun and enjoyment. In the context of Technology adaptation, most studies discovered that HM acting as an intrinsic motivator and increased the adoption rate in the mind of the consumer (van der Heijden, 2004: Kim et al., 2007).Various past researches suggested that Hedonic motivation is perceived enjoyment and can largely influence the behavioural intention to use the technology (van der Heijden 2004; Thong, Hong and Tam, 2006).Therefore, it is hypothesized that:

H5. Hedonic motivation (HM) will have a significant influence on Behavioural intention (BI) to use e payment services in India.

\section{H. Habit (HT)}

Habit has been defined as "the extent to which people tend to perform behaviors automatically because of learning" (Limayem et al. 2007, Venkatesh et al., 2012), while Kim et al. (2005) "equate habit with automaticity". Aarts and Dijksterhuis (2000) mentioned HT is "strongly associated with the behaviour frequency that will be performed automatically whereby the higher occurrence rate, the more extent of the HTs". Different author had different context about habit in e-payment adoption; the author has conceptualized habit as a preceding behaviour. Kim et al. (2005) in his research found that past usage experience influences behavioural intention. According to Blut et al. (2016)it is presumes that repeated performance of behaviour produces habituation and that behaviour can be directly activated by stimulus cues. In the same line similar situation can lead automatic response. Therefore, it is hypothesized that:

H6. Habit (HT) will have a significant influence on Behavioural intention (BI) to use e payment services in India.

\section{Trust in Internet (TI)}

Trust in the internet is often identified as institution-based trust (Carter and Be'langer, 2005; Be'langer and Carter, 2008), which is "the belief that needed structural conditions are present (e.g. in the internet) to enhance the probability of achieving a successful outcome in an endeavour like e-commerce" (McKnight et al., 2002, p. 339). According to (Mayer et al., 1995) trust is " the willingness of a party to be vulnerable to the actions of another party based on the expectation that the other will perform a particular action important to the trust or, irrespective of the ability to monitor or control that other party". Various past researches are indicating vital role of trust in internet in adoption of $\mathrm{e}$ payment services. (Carter and Belanger, 2005; Chang et al., 2005).In context of E-payment, trust plays an important role in creating positive intention to use the services (Kim et al., 2010; Ooiand Tan, 2016; Mallat, 2007; Shankar and Datta, 2018, Sharma et al. 2019). In the context of developing economy like India, the research has done in similar emerging economy in Taiwan and Singapore by Chang et al. (2005) and Phang et al. (2005) and they have concluded that trust in the internet (security and privacy) effect significantly on intention to use e-government services. It was concluded that security, trust, perceived advantage, assurance seals, perceived risk and usability were most important. Hence, it is hypothesized that:

H7. Trust in internet (TI) will have a significant influence on Behavioural intention (BI) to use e payment services in India.Paper

\section{J. Trust in Government (TG)}

"Trust in government" can be defined as the public's assessment of government based on their perceptions of political authorities', agencies' and institutions' integrity and capability to provide services according to the expectations held by the citizens (Be'langer and Carter, 2008; Levi and Stoker, 2000; Mayer et al., 1995). As mentioned by (Abrazhevich, 2004), It can also define as confidence of consumer that nobody will misuse their money and personal information against their personnel interest. Even when the system is no so perfect, consumers want to believe that banks, companies, merchants, credit card companies and mall will not misuse their personal information. Previous research indicates the importance of addressing the role of trust in government in influencing e-government adoption (Be'langer and Carter, 2008; Carter and Be'langer, 2005; Welch et al., 2005). According to Alomari, M. et al. (2012), trust in government plays a major role in adoption of e-government services. Therefore, it is hypothesized that:

H8. Trust in Government (TG) will have a significant influence on Behavioural intention (BI) to use e payment services in India.

\section{K. Government Support (GS)}

According to Chong et al. (2010) government plays a vital role in encouraging their citizens to use e payment services. In addition he has also quoted that how Malaysian government has supported the people in assessing e government services via commercials in television and radio. Chong et al. (2010) also highlighted the role of government apart from promotion and supporting with infrastructures, government can support the citizens by framing adequate cyber law to improve users' confidence in e-payment. Government support is the main factor in influencing the Internet banking adoption (Jaruwachirathanakul and Fink, 2005; Tornatzky and Klein, 1982). There are many ways to extent Government support to the citizens such as developing digital infrastructure, establishing fibre opt cabling. Countries' like Singapore, Japan and Malaysia has heavily invested in IT infrastructure (Chong and Ooi, 2008). In the 
similar study Tan and Teo (2000) observed that government support influences adoption of e banking in Singapore. Therefore, it is hypothesized that:

H9. Government Support (GS) will have a significant influence on Behavioural intention (BI) to use e payment services in India.

\section{RESEARCH MODEL}

Based on the aforementioned literature, we posit that UTAUT factors, Trust in Technology \& Government and Government support have a significant impact on behavioral intention of rural Indians in adoption of e payment system. The proposed model is shown in Figure I.

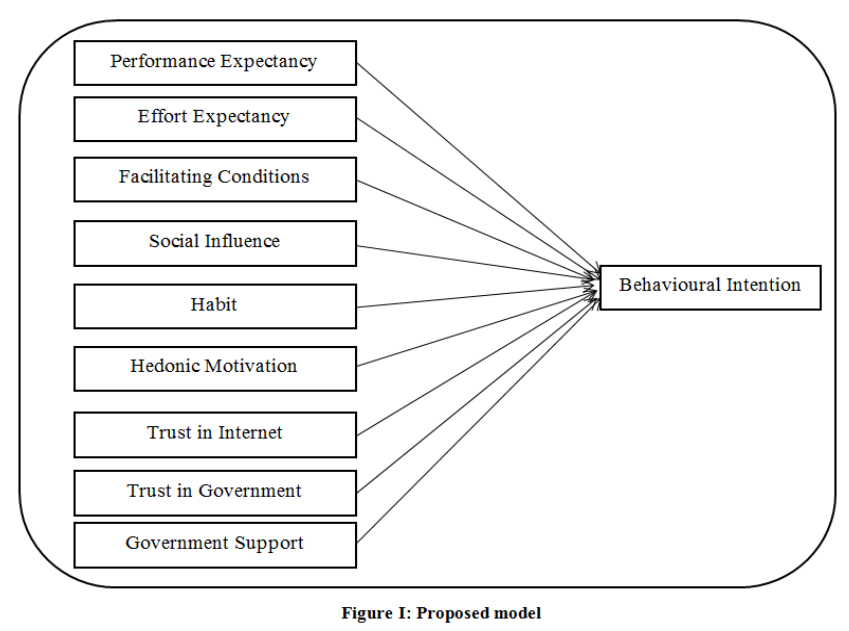

\section{RESEARCH METHODOLOGY}

\section{A. Sample}

Target population comprises of those citizens residing in rural part of India. The present study has collected relevant primary data with the help of structured questionnaire by using non-probability convenience sampling method. The questionnaire was converted in to Gujarati (Local) language for the better understanding of rural people. Personal interview method was used to collect data from respondents To achieve the desired objective, based upon convenience sampling, the data was collected from 316 citizens from rural part of India. Amongst the respondents, $63.3 \%$ were male and $36.7 \%$ were female. Majority of the participants $(n=98$, $31 \%)$ fall into age category of $30-40$ years, $26.3 \%(n=83)$ of the participants in the age group of 21-30 years. Moreover, $59.5 \%$ of participants $(n=188)$ were studied up to high school level, $16.5 \%(n=52)$ graduates and only $15.8 \%(n=50)$ were post graduates indicating sample domination of less educated people. Level of income is also categorized and there were $45.9 \%(n=145)$ less than $15000 /$ month income group and 20.9 ( $n=66)$ were from 15000 to 25000 group also indicating sample dominance of less income group people.

\section{B. Measures}

All UTAUT 2 variables (Performance Expectancy (PE), Effort expectancy (EE), Social influence (SI), Facilitating conditions (FC), Hedonic motivation (HM), Habit (HT) and Behavioural Intention (BI)were adapted from previous studies by Venkatesh et al. (2012)and further used by Tak and Panwar, (2017). While "trust" factor comprises two components: trust of the internet and trust in the government which were taken from Alomari, M. K. et al. (2010) study. The measure called "Government Support (GS)"was adopted from Yee-Loong Chong et al. (2010) study. All these constructs were measured on five- point, Likert-types scale with strongly disagree (1) to strongly agree (5).

Table I: Measures Used in the Study

\begin{tabular}{|c|c|c|c|}
\hline Variable & Specification & Items & $\begin{array}{c}\text { Cronbach's } \\
\text { Alpha }\end{array}$ \\
\hline $\begin{array}{l}\text { Performance } \\
\text { Expectancy }\end{array}$ & $\begin{array}{l}\text { Four-item, five } \\
\text { point likert type } \\
\text { scale }\end{array}$ & $\begin{array}{l}\text { "I would find e-payment useful in my day-to-day life". } \\
\text { "Use of e-payment enables me to accomplish tasks more quickly". } \\
\text { "Use of e-payment increases my productivity". } \\
\text { "Use of e-payment enhances my effectiveness" }\end{array}$ & 0.838 \\
\hline $\begin{array}{c}\text { Effort } \\
\text { expectancy }\end{array}$ & $\begin{array}{l}\text { Four-item, five } \\
\text { point likert type } \\
\text { scale }\end{array}$ & $\begin{array}{l}\text { "Learning how to use e-payment is easy for me". } \\
\text { "My interaction with e-payment is clear and understandable" } \\
\text { "I find e-payment easy to use." } \\
\text { "It is easy for me to become skillful at using e-payment" }\end{array}$ & 0.742 \\
\hline $\begin{array}{c}\text { Social } \\
\text { influence }\end{array}$ & $\begin{array}{l}\text { Three-item, five } \\
\text { point likert type } \\
\text { scale }\end{array}$ & $\begin{array}{l}\text { "People who are important to me think that I should use } \\
\text { e-payment" } \\
\text { "People who influence my behaviour think that I should use } \\
\text { e-payment" } \\
\text { "People whose opinions that I value prefer that I use e-payment" }\end{array}$ & 0.692 \\
\hline $\begin{array}{l}\text { Facilitating } \\
\text { conditions }\end{array}$ & $\begin{array}{l}\text { Four-item, five } \\
\text { point likert type } \\
\quad \text { scale }\end{array}$ & $\begin{array}{l}\text { "I have the resources necessary to use e-payment" } \\
\text { "I have the knowledge necessary to use e-payment" } \\
\text { "e-payment are compatible with other methods I use for payment" } \\
\text { "I can get help from others when I have difficulties using } \\
\text { e-payment" }\end{array}$ & 0.675 \\
\hline
\end{tabular}




\begin{tabular}{|c|c|c|c|}
\hline $\begin{array}{c}\text { Hedonic } \\
\text { motivation }\end{array}$ & $\begin{array}{l}\text { Three-item, five } \\
\text { point likert type } \\
\text { scale }\end{array}$ & $\begin{array}{l}\text { "Using e-payment is fun" } \\
\text { "Using e-payment is enjoyable" } \\
\text { "Using e-payment is very entertaining" }\end{array}$ & 0.675 \\
\hline Habit & $\begin{array}{l}\text { Four-item, five } \\
\text { point likert type } \\
\text { scale }\end{array}$ & $\begin{array}{l}\text { "The use of e-payment has become a habit for me" } \\
\text { "I am addicted to using e-payment" } \\
\text { "I must use e-payment" } \\
\text { "Using e-payment has become natural to me" }\end{array}$ & 0.757 \\
\hline $\begin{array}{c}\text { Behavioral } \\
\text { intention }\end{array}$ & $\begin{array}{l}\text { Three-item, five } \\
\text { point likert type } \\
\text { scale }\end{array}$ & $\begin{array}{l}\text { "I intend to continue using e-payment in the future" } \\
\text { "I will always try to use e-payment in my daily life" } \\
\text { "I plan to continue to use e-payment frequently" }\end{array}$ & 0.688 \\
\hline $\begin{array}{l}\text { Trust in } \\
\text { internet }\end{array}$ & $\begin{array}{l}\text { Four-item, five } \\
\text { point likert type } \\
\text { scale }\end{array}$ & $\begin{array}{l}\text { "The internet has enough safeguards to make me feel comfortable } \\
\text { using it for e-payment" } \\
\text { "In general, the internet is now a robust and safe environment in } \\
\text { which to transact." } \\
\text { "I am confident that the data I submit online/mobile will not be } \\
\text { misused and will be treated confidentially." } \\
\text { "I am confident that no fraud will be committed." }\end{array}$ & 0.621 \\
\hline $\begin{array}{c}\text { Trust in } \\
\text { Government }\end{array}$ & $\begin{array}{l}\text { Four-item, five } \\
\text { point likert type } \\
\text { scale }\end{array}$ & $\begin{array}{l}\text { "Government can be trusted to carry out e-payment transactions } \\
\text { faithfully." } \\
\text { "I trust government because they keep my best interests in mind." } \\
\text { "I am confident that the payment I submit though e-payment } \\
\text { modes will be processed." } \\
\text { "I am confident that the government will provide me reliable and } \\
\text { up to date information about my payment." }\end{array}$ & 0.857 \\
\hline $\begin{array}{c}\text { Government } \\
\text { support }\end{array}$ & $\begin{array}{l}\text { Four-item, five } \\
\text { point likert type } \\
\text { scale }\end{array}$ & $\begin{array}{l}\text { "Government encourages and promotes the usage of e-payment" } \\
\text { "The internet infrastructure and facilities such as bandwidth is } \\
\text { sufficient for e-payment" } \\
\text { "The government is driving the development of e-payment" } \\
\text { "The government has good regulations and laws for e-payment" }\end{array}$ & 0.857 \\
\hline
\end{tabular}

\section{Scale Reliability Statistics}

The relationship between factors influencing e-payment Assessment of strength of scale has been made through reliability analysis. To do so, Cronbach's coefficient alphaan indicator of internal consistency was determined (Cronbach's, 1991).Cronbach's alpha indicates the degree to which items of a scale making up a variable shared a common core. As an evidence of good internal reliability, the Cronbach's alpha values are required to higher than 0.6 (Nunnally, 1978). Table I indicates that the alpha values for all constructs were above than the threshold confirming that scales are reliable.

\section{TESTING OF HYPOTHESIS}

The relationship between factors influencing e-payment was tested using a multiple regression analysis. According to Hair et al.(1998), multiple regression analysis is useful to establish the relationship between a single dependent variable and several independent variables.
In accordance with hypotheses postulated in aforementioned section, summated scale of dependent variable (i.e. Behavioral intention (BI) to use e-payment) and all independent variable (i.e. Performance Expectancy (PE), Effort expectancy (EE), Social influence (SI), Facilitating conditions (FC), Hedonic motivation (HM), Habit (HT), Trust in Internet (TI), Trust in Government (TG) and Government support (GS)) was calculated. Enter method was used indicating all the independent variables were considered at a same time. SPSS 16.0 windows version was used to do data analysis. Regression analysis was performed to determine (a) model fit (b) explanatory power of a model and (c) significance of each predictor used.

Table II: Regression analysis with behavioral Intention as Dependent variable

\begin{tabular}{|c|c|c|c|c|c|c|}
\hline Variables & Unstandardized $\beta$ & Std. Error & Std. $\beta$ & $\mathbf{t}$ & Sig. & VIF \\
\hline Performance Expectancy (PE) & .101 & .036 & .119 & 2.827 & $0.005^{*}$ & 1.176 \\
\hline Effort expectancy (EE) & .098 & .048 & .084 & 2.023 & $0.044 *$ & 1.141 \\
\hline Social Influence (SI) & .061 & .054 & .065 & 1.125 & 0.262 & 2.190 \\
\hline Facilitating conditions (FC) & .133 & .044 & .157 & 2.986 & $0.003 *$ & 1.826 \\
\hline Hedonic motivation (HM) & .281 & .049 & .305 & 5.732 & $0.000 *$ & 1.877 \\
\hline Habit (HT) & .108 & .036 & .130 & 2.979 & $0.003 *$ & \\
\hline
\end{tabular}




\begin{tabular}{|l|c|c|c|c|c|c|}
\hline Trust in Internet (TI) & .064 & .053 & .052 & 1.223 & 0.222 & 1.198 \\
\hline Trust in Government (TG) & .168 & .043 & .190 & 3.887 & $0.000^{*}$ & 1.585 \\
\hline Government support (GS) & .111 & .044 & .124 & 2.517 & $0.012^{*}$ & 1.141 \\
\hline
\end{tabular}

Note: $F=39.834 ; d f=315 ; R=0.526 ; R$-Square $=0.540 ; * p<0.05$ level

Table II demonstrated that model is fit $(\mathrm{F}=39.83$; $\mathrm{p}<0.05)$. It was also found that nine independent variables explain 54.0 per cent of variation in Behavioral intention to use e-payment. Moreover, the model revealed that five factors influencing e-payment intention namely, Performance Expectancy (PE) $(\beta=0.101, p=0.005)$,Effort expectancy $(\mathrm{EE})$ $(\beta=0.098, p=0.044)$, Facilitating conditions $(\mathrm{FC})(\beta=0.133$, $\mathrm{p}=0.003)$, Hedonic motivation $(\mathrm{HM})(\beta=0.281$, $\mathrm{p}=0.000)$,Habit $(\mathrm{HT})(\beta=0.108, \mathrm{p}=0.03)$, Trust in Government (TG) $(\beta=0.168, \quad \mathrm{p}=0.000)$ and Government support $(\mathrm{GS})(\beta=0.111, \mathrm{p}=0.012)$ were found to have a significant relationship with Behavioral intention (BI) about e-payment. Thus, hypotheses; H1, H2, H4, H5, H6, H8 and $\mathrm{H} 9$ was confirmed. Social Influence (SI) $(\beta=0.061, \mathrm{p}=0.261)$ and Trust in internet (TI) $(\beta=0.064, p=0.222)$ were found to have a non-significant relationship with Behavioral intention (BI) about e-payment. Thus hypotheses $\mathrm{H} 3$ and $\mathrm{H} 7$ were not confirmed. No issues of multicollinearity were evident as all displayed VIF (variance inflation factor) statistics were not more than 10 (Myer, 1990).

\section{DISCUSSION AND IMPLICATION OF THE} STUDY

From the above findings it is relieved that UTAUT2 variable trust in government, trust in internet and government support having influence on behavioral intension of rural people of India. This study was aimed to investigate behavioural intention of rural people of India towards e-payment. Regression was used which showed that factors with UTAUT 2 model deemed fit with an explanatory power of 54.0 per cent. Put together, results of the study were as follow:

1. Performance Expectancy (PE) (significant, positive; $\beta=0.101$ )

2. Effort expectancy (EE) (significant, positive; $\beta=0.098$ )

3. Social Influence (SI) (Insignificant)

4. Facilitating conditions (FC) (significant, positive; $\beta=0.133$ )

5. Hedonic motivation (HM) (significant, positive; $\beta=0.281)$

6. Habit (HT) (significant, positive; $\beta=0.108$ )

7. Trust in Internet (TI) (Insignificant)

8. Trust in Government (TG) (significant, positive; $\beta=0.168$ )

9. Government support (GS) (significant, positive; $\beta=0.111$ )

Higher beta value of Hedonic motivation (HM) indicating that e payment is enjoyable and entertaining for India rural people. So policy makers should made the payment system in such a way that people can get more fun and enjoyment while making e payments. Results are also showing Trust in Government (TG) is an important variable in framing behavioral intention of the people. It may be the case that people do not find the government trustworthy due to their non-transparent practices while delivering public services and that's why they are still reluctant to adopt government mobile wallets, Bank online applications and many other payment modes. Thus, the government should make the system more transparent and full proof to build the trust.

Facilitating conditions (FC) is also positively influencing behavioral intention. Many of the rural India people are not having the resources necessary to use e-payment and they are also facing difficulties in operating smart phones and laptops. So Government should first provide the necessary electronics gadgets and then should launch the awareness or training program in rural area to make the people compatible in using e payment system. Result evident that government should extend the support to the rural people to complete digital India mission. The government can extent its support to the rural people by making the e payment system easy and user friendly. There should be easy process to get debit/credit card, Mobile wallet or POS. As the Habit (HT) is also positively influencing the behavioral intention, Policy maker should give emphasis on converting more and more people from cash payment to e payment. Once they will become habitual to use this then they will continue using it.

Results reviled that the major construct of UTUAT model, Performance Expectancy (PE), Effort expectancy (EE) and Facilitating conditions (FC)was highly related to Behaviour intention about e-payment as consistent in past study (Tak and Panwar, 2017). It implies that the citizens discover the payment system to be useful in their day to day life to accomplish tasks more quickly. They also believe that it will increase their productivity and effectiveness. Beta value in regression is concluding that compared with the other variable rural people are giving less importance to Performance Expectancy (PE), Effort expectancy (EE).Moreover, Social Influence (SI) and Trust in internet (TI) were found to have a non-significant relationship with Behavioral intention (BI). It concludes that people are less likely to get influence by the other people and they are sceptic about the privacy and security of the internet system in India. Government should ensure people that they will not be cheated or been victim of cybercrime.

\section{CONCLUSION}

This study benefits to practitioners as well as researchers. For government, the findings might give contributions theoretically and practically. Lack of studies in the area of e-payment Specifically in G2C and rural areas is one of the reasons why such study needs to be conducted. Study makes the picture clear about of what is going on and the current status of

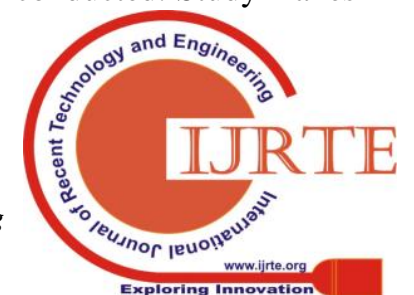


e-payment implementation in India. With the help of theoretical models such as UTAUT 2 and other contributing factors such as Government support, Trust in internet and trust in Government have been studied to explain e payment adoption.

Thus, based on the findings, current study concludes that the UTAUT variable and other contributing factors such as Government support, Trust in internet and trust in Government are influencing e payment adoption intention of the rural people of India.

The study results are little contradicting the most previous works in these areas as main variable of the UTAUT 2 are showing less beta value and having less influence on behavioural intention. And as Indian traditional consumer they are expecting government support to adopt the e payment. Further more specifically in the rural Indian areas majority of people are not using e payment and reluctant to adopt it. So, now days though Indian government is heavily communicating and creating buzz about digital India and cashless economy in their campaigns but in reality, it is generally visible in urban India and not in rural areas.

\section{LIMITATIONS AND FUTURE SCOPE OF THE STUDY}

This study has several limitations listed as follow: (a) the survey was only targeting rural citizens residing in Gujarat region as a sample, thus sample of respondents from various geographical areas may be able to provide clearer picture of e-payment intentions. (b) The focus of the study was only intention about e-payment, so actual adoption of e-payment should be considered in further study. This is also extended to other G2C e-payment application services. (c)The causal relationships between various variables have not been investigated. Future researcher can develop more specific scale by incorporating link between various variables. (d) The future researchers can determine the others important factors that influence the e- payment intention. There is scope for further research in future for other factors like privacy, security, and data protection which might influence citizen's intention about e-payment services.

\section{REFRENCES}

1. Aarts, H., \&Dijksterhuis, A. (2000). Habits as knowledge structures: Automaticity in goal-directed behavior. Journal of personality and social psychology, 78(1), 53.

2. Abrazhevich, D. (2004). Electronic payment systems: A user-centered perspective and interaction design. Dennis Abrazhevich.

3. Abrazhevich, D. (2004). Electronic payment systems: A user-centered perspective and interaction design. Dennis Abrazhevich.

4. Agarwal, R., \&Karahanna, E. (2000). Time flies when you're having fun: Cognitive absorption and beliefs about information technology usage. MIS quarterly, 665-694.

5. Alomari, M. K., Sandhu, K., \& Woods, P. (2010).Measuring social factors in e-government adoption in the Hashemite Kingdom of Jordan. International Journal of Digital Society (IJDS), 1(2), 163-172.

6. Alomari, M., Woods, P., \&Sandhu, K. (2012). Predictors for e-government adoption in Jordan: Deployment of an empirical evaluation based on a citizen-centric approach. Information Technology \& People, 25(2), 207-234.

7. Bélanger, F., \& Carter, L. (2008). Trust and risk in e-government adoption. The Journal of Strategic Information Systems, 17(2), 165-176.

8. Blut, M., Wang, C., \&Schoefer, K. (2016). Factors influencing the acceptance of self-service technologies: A meta-analysis. Journal of Service Research, 19(4), 396-416.

9. Bresnahan, M. J., Levine, T. R., Shearman, S. M., Lee, S. Y., Park, C. Y., \&Kiyomiya, T. (2005).A multimethodmultitrait validity assessment of self-construal in Japan, Korea, and the United States. Human Communication Research, 31(1), 33-59.

10. Brown, S. A., \& Venkatesh, V. (2005). Model of adoption of technology in households: A baseline model test and extension incorporating household life cycle. MIS quarterly, 29(3).

11. Carter, L., \&Bélanger, F. (2005). The utilization of e-government services: citizen trust, innovation and acceptance factors. Information systems journal, 15(1), 5-25.

12. Chang, M.K., Cheung, W. and Lai, V.S. (2005), "Literature derived reference models for the adoption of online shopping", Information \& Management, Vol. 42, pp. 543-59.

13. Chong, A.Y.L., Chan, F.T.S. and Ooi, K.B. (2012), "Predicting consumer decisions to adopt mobile commerce: cross country empirical examination between China and Malaysia", Decision Support Systems, Vol. 53 No. 1, pp. 34-43.

14. Cronbach, L. J. (1991). Emerging views on methodology.

15. Goldfinger, C., \& Perrin, J. (2001, October).E-Finance and Small and Medium Size Enterprises (SMEs) in Developing and Transition Economies. In UNCTAD background papers, United Nations Conference on trade and Development, Geneva (pp. 45-78).

16. Im, I., Hong, S., \& Kang, M. S. (2011). An international comparison of technology adoption: Testing the UTAUT model. Information \& management, 48(1), 1-8.

17. Im, I., Hong, S., \& Kang, M. S. (2011). An international comparison of technology adoption: Testing the UTAUT model. Information \& management, 48(1), 1-8.

18. Jaruwachirathanakul, B., \& Fink, D. (2005). Internet banking adoption strategies for a developing country: the case of Thailand. Internet research, 15(3), 295-311.

19. Jiang, L., Yang, Z., \& Jun, M. (2013).Measuring consumer perceptions of online shopping convenience. Journal of Service Management, 24(2), 191-214.

20. Khosrow-Pour, M. (Ed.). (2008). E-government diffusion, policy, and impact: advanced issues and practices: advanced issues and practices. IGI Global.

21. Kim, C., Mirusmonov, M. and Lee, I. (2010), “An empirical examination of factors influencing the intention to use mobile payment", Computers in Human Behavior, Vol. 26 No. 3, pp. 310-22

22. Kim, D. J., Cho, B., \&Rao, H. R. (2000). Effects of consumer lifestyles on purchasing behavior on the internet: A conceptual framework and empirical validation. Proceedings of The Twenty First International Conferences on Information Systems, Brisbane, Queensland, Australia, 688-695.

23. Kim, H. W., Xu, Y., \& Gupta, S. (2012). Which is more important in Internet shopping, perceived price or trust?. Electronic Commerce Research and Applications, 11(3), 241-252.

24. Kim, M. K., Chang, Y., Wong, S. F., \& Park, M. C. (2015).The effect of perceived risks and switching barriers on the intention to use smartphones among non-adopters in Korea. Information Development, 31(3), 258-269.

25. Kim, S. S., and Malhotra, N. K. 2005a. "A Longitudinal Model of Continued IS Use: An Integrative View of Four Mechanisms Underlying Postadoption Phenomena," Management Science (51:5), pp. 741-755.

26. Koenig-Lewis, N., Marquet, M., Palmer, A., \& Zhao, A. L. (2015) Enjoyment and social influence: predicting mobile payment adoption. The Service Industries Journal, 35(10), 537-554

27. Levi, M., \& Stoker, L. (2000).Political trust and trustworthiness.Annual review of political science, 3(1), 475-507.

28. Lewis, W., Agarwal, R., and Sambamurthy, V. (2003). Sources of influence on beliefs about information technology use: An empirical study of knowledge workers. MIS Quarterly, 27(4), 657-678

29. Limayem, M., Hirt, S. G., \& Cheung, C. M. (2007). How habit limits the predictive power of intention: The case of information systems continuance. MIS quarterly, 31(4).

30. Lu, H.P. and Yu-Jen Su, P. (2009), "Factors affecting purchase intention on mobile shopping web sites".Internet Research, 19(4), pp. 442-458. http://dx.doi.org/10.1108/10662240910981399

31. LU, Y., Deng, Z. and Wang, B. (2010) Exploring factors affecting Chinese consumers' usage of short message service for personal communication. Information Systems Journal, 20(2): 183-208. 
32. Mahadeo, J. D. (2009). Towards an Understanding of the Factors Influencing the Acceptance and Diffusion of e-Government Services. Electronic Journal of E-government, 7(4).

33. Mallat, N. (2007). Exploring consumer adoption of mobile payments-A qualitative study. The Journal of Strategic Information Systems, 16(4), 413-432.

34. Mayer, R. C., Davis, J. H., \&Schoorman, F. D. (1995).An integrative model of organizational trust. Academy of management review, 20(3), 709-734.

35. Mayer, R. C., Davis, J. H., \&Schoorman, F. D. (1995).An integrative model of organizational trust. Academy of management review, 20(3), 709-734.

36. Mayer, R., Davis, J., and Shoorman, F. “An Integrative Model of Organizational Trust," The Academy of Management Review (20:3), 1995, pp. 709-734

37. Mehta, R., \&Sivadas, E. (1995). Direct marketing on the Internet: An empirical assessment of consumer attitudes. Journal of Direct Marketing, 9(3), 21-32.

38. Nunnally, Jum C. 1978 (second edition).Psychomtietrictheory. New York: McGraw-Hill.

39. Ooi, K. B., \& Tan, G. W. H. (2016). Mobile technology acceptance model: An investigation using mobile users to explore smartphone credit card. Expert Systems with Applications, 59, 33-46.

40. Panurach, P. (1996). Money in electronic commerce: Digital cash, electronic fund transfer, and ecash. Communications of the ACM, 39(6), 45-51.

41. Phang, C.W., Sutanto, J., Li, Y. and Kankanhalli, A. (2005), "Senior citizens' adoption of e-government: in quest of the antecedents of perceived usefulness", paper presented at the 38th Hawaii International Conference on System Sciences, Big Island, HI, January 3-6.

42. Puschel, J., Mazzon, J.A. and Hernandez, J.M.C. (2010) 'Mobile banking: proposition of an integrated adoption intention framework', International Journal of Bank Marketing, Vol. 28, No. 5, pp.389-409.

43. Shankar, A., \&Datta, B. (2018). Factors affecting mobile payment adoption intention: An Indian perspective. Global Business Review, 19(3_suppl), S72-S89.

44. Sharma, S. K., Sharma, H., \& Dwivedi, Y. K. (2019).A Hybrid SEM-Neural Network Model for Predicting Determinants of Mobile Payment Services. Information Systems Management, 1-19.

45. Tak, P., \&Panwar, S. (2017). Using UTAUT 2 model to predict mobile app based shopping: evidences from India. Journal of Indian Business Research, 9(3), 248-264.

46. Tan, G. W. H., Ooi, K. B., Sim, J. J., \&Phusavat, K. (2012). Determinants of mobile learning adoption: An empirical analysis. Journal of Computer Information Systems, 52(3), 82-91.

47. Tan, M., \&Teo, T. S. (2000).Factors influencing the adoption of Internet banking. Journal of the Association for information Systems, 1(1), 5.

48. Taylor, S., \& Todd, P. (1995).Assessing IT usage: The role of prior experience. MIS quarterly, 561-570

49. Thong, J. Y., Hong, S. J., \& Tam, K. Y. (2006). The effects of post-adoption beliefs on the expectation-confirmation model for information technology continuance. International Journal of Human-Computer Studies, 64(9), 799-810.

50. Tornatzky, L. G., \& Klein, K. J. (1982). Innovation characteristics and innovation adoption-implementation: A meta-analysis of findings. IEEE Transactions on engineering management, (1), 28-45.

51. Van der Heijden, H. (2004). User acceptance of hedonic information systems. MIS quarterly, 695-704.

52. Venkatesh, V., Morris, M. G., Davis, G. B., \& Davis, F. D. (2003). User acceptance of information technology: Toward a unified view. MIS quarterly, 425-478

53. Venkatesh, V., Thong, J. Y., \&Xu, X. (2012). Consumer acceptance and use of information technology: extending the unified theory of acceptance and use of technology. MIS quarterly, 36(1), 157-178

54. Williams, M. D., Rana, N. P., \& Dwivedi, Y. K. (2015). The unified theory of acceptance and use of technology (UTAUT): a literature review. Journal of Enterprise Information Management, 28(3), 443-488.

55. Yee-Loong Chong, A., \&Ooi, K. B. (2008). Adoption of interorganizational system standards in supply chains: an empirical analysis of RosettaNet standards. Industrial Management \& Data Systems, 108(4), 529-547.

56. Yee-Loong Chong, A., Ooi, K. B., Lin, B., \& Tan, B. I. (2010).Online banking adoption: an empirical analysis. International Journal of bank marketing, 28(4), 267-287.

57. Yee-Loong Chong, A., Ooi, K. B., Lin, B., \& Tan, B. I. (2010).Online banking adoption: an empirical analysis. International Journal of bank marketing, 28(4), 267-287.

58. Yu, C. S. (2012). Factors affecting individuals to adopt mobile banking: Empirical evidence from the UTAUT model. Journal of electronic commerce research, 13(2), 104

\section{AUTHORS PROFILE}

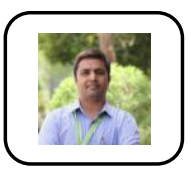

Prof. Vishal A. Acharya is an assistant professor in the area of Finance at V. M. Patel institute of management, Ganpa University. He has done his Graduation in B.Com from Hemchandracharya North Gujarat University in 2004. He has done his Master in Business Administration with Finance specialization from V. M. Patel College of Management Studies, Ganpat University, Mehsana in 2007. He has Pursuing his Ph.D. in the field of management and in the area of Financial Risk Tolerance of Investors from Kadi Sarva Vishwavidhyala, Gandhinagar. He is interested to explore research areas like Investment behaviour, mobile banking and internet banking, mutual fund investment factors etc. He has published several papers in the many scholarly journals. He has received First Prize in Best Research Paper Award in the "National Conference on Emerging Issues in Accounting \& Commerce" organized by Faculty of Social Science and Humanities, GNU.

Prof. S.O. Junare is Professor of Forensic Accounting and

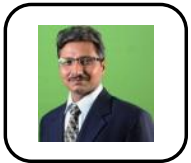
Dean, Faculty of Management at Gujarat Forensic Science University, Gandhinagar. Recently he has been appointed as a Director at Institute of Forensic Science, one of the prominent constituent institutes of Gujarat Forensic Sciences University.

Prof. Junare has diversified combination of talent and education. He earned his Bachelor's degree in Commerce and Master Degrees in Commerce and Philosophy from Amravati University and his MBA and LLB (Special) degrees from Gujarat University. He completed his $\mathrm{PhD}$ from University of Pune in 2000. He has also undergone FDPM program with specialization in Financial Management at IIM Ahmedabad in 1995-96.

Prior joining to Gujarat Forensic Sciences University he was working at Raksha Shakti University as a Registrar. He has an extensive experience of more than 25 years in management education. He has worked as Assistant Professor, Associate Professor, Professor and Director at National Council for Cooperative Training, (Govt of India) and National Institute of Cooperative Management, Gandhinagar from 1992 to 2016. He has also served as Statistician, Directorate of Economic Research at Khadi and Village Industries Commission, Mumbai. He was also appointed as a Dean of Faculty of Management at Gujarat Technological University, Ahmedabad from 2009 to 2016. He is also holding an additional charge as In-charge Director of Institute of Training at GFSU Gandhinagar.

A highly recognized researcher, Prof. Junare is a member of various committees and boards at various universities and educational institutes and Government For his outstanding contribution to management education and training, he has received many accolades including Best Teacher award in 2014 and in 2017 from Higher Education Forum, Mumbai. He is also a chief editor of NICM Bulletin: A Journal of Cooperation and Management (since 2003). Prof. Junare is also a member of the Centre of Professional Excellence in Cooperatives, NABARD [BIRD] Lucknow.

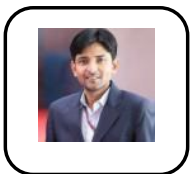

Dr. Dharmesh Gadhavi is an assistant professor in the area of marketing at V. M. Patel institute of management, Ganpat University. He has done his Graduation in Chemical Engineering from Nirma Institute of Technology, Gujarat University in 2003. He has done his post-graduation in Business Administration with marketing specialization from S.K. School of Business Management, North Gujarat University, Patan in 2006. He has completed his $\mathrm{PhD}$ in the field of management and in the area of Cause related marketing from North Gujarat University in 2015. He is interested to explore research areas like digitalization in marketing practices, Service marketing, Retailing, Societal marketing. He has attended many national and international conferences. He has published several papers in the many scholarly journals including Journal of Retailing and Consumer Services, International Review on Public and Non Profit Marketing and International Journal of Business and Emerging Markets. He also has four awards for best research papers in his credential. Apart from this, he is an ad-hoc reviewer in many reputed journals like Marketing Intelligence and Planning.S 